\title{
A Study of Corrective Feedback and Learner's Uptake in Classroom Interactions
}

\author{
Fatemeh Esmaeili \\ Azarbayjan Shahid Madani University, Iran \\ E-mail: F.esmaeili2@yahoo.com \\ Biook Behnam \\ Department of English, Tabriz Beanch, Islamic Azad University, Tabriz, Iran \\ E-mail: Behnam_biook@yahoo.com
}

Received: 17-02- 2014

Accepted: 04-04- 2014

Published: 01-07- 2014

doi:10.7575/aiac.ijalel.v.3n.4p.204

URL: http://dx.doi.org/10.7575/aiac.ijalel.v.3n.4p.204

\begin{abstract}
The present study aims to examine corrective feedback and learner uptake in classroom interactions. Inspired by Lyster and Ranta's corrective feedback framework (1997), this study intends to describe and analyze the patterns of corrective feedback utilized by Iranian teachers, and learners' uptake and the repair of those errors. To this aim, 400 minutes of classroom interaction from three elementary EFL classes which comprised 29 EFL learners were audiotaped and transcribed. The learners were within age range of 16-29 and were native speakers of Turkish language. The teachers were within 26-31 age range and had 3-4 years experience of teaching and hold MA degree in TOEFL. Analysis of data constituted the frequency of six different feedback types used by three teachers, in addition distribution of learners' uptake following each feedback type. The findings indicated that among six corrective feedback types, recast was the most frequent feedback utilized by teachers although it did not lead to high amount of learner uptake. Metalinguistic feedback, elicitation and clarification request led to higher level of uptake. It was also found that explicit feedback was more effective than implicit feedback in promoting learner uptake.
\end{abstract}

Keywords: Corrective Feedback, Learner Uptake, Classroom Interaction, EFL Teachers, EFL Learners

\section{Introduction}

The study of learner errors has been a controversial issue in SLA field. There have been contrasting attitudes on how to deal with students' erroneous utterances. Behaviorist teaching models viewed errors as inevitable and harmful to the process of language acquisition which required immediate correction by the teacher (Russell, 2009). Brooks (1960) stated "Like sin, error is to be avoided and its influence overcome ... the principal way of over-coming it is to shorten the time lapse between the incorrect response and a presentation once more of the correct model" (p. 56 cited in Russell, 2009). However, in the 1970s the research findings of naturalistic SLA degraded the principles of behaviorist models of instruction and questioned value of teaching grammar and correcting learners' erroneous utterances in the second language classroom (Russell, 2009). Krashen (1981) viewed error correction as an unnecessary task which negatively impacted language learning process. Krashen (1982, 1985 cited in El Tateway 2002) believed SLA is an implicit process which is the result of providing students with comprehensible input.

With the emergence of communicative approach, error correction underwent a radical shift (Russell, 2009). Communicative language teaching made a balance between principles of Audiolingualism and Cognitivism and recognized errors as evidence of learners' interlanguage development, not as a sign of lack of linguistic knowledge which is to be avoided in language classes. (Rezaei , Mozaffari, Atefet, 2011). Fluency was regarded as an important objective of language teaching which required teachers avoid interrupting learners' production and leave some errors uncorrected (Rezaei et al, 2011). Since communicative language teaching emphasized meaning and negotiation, the correction of grammatical errors was not the primary focus. However, when learners' accuracy was addressed, errors were corrected in appropriate context (Omaggio Hadley, 2001 cited in Russell, 2009).

In the 1990s, researchers suggested that error correction with focus on form plays critical role in language acquisition (Ellis, 1993, 1994; Long, 1996; Schmidt, 1990, 1995 ). Long (1996 cited in Foster \& Ohta, 2005) in his interaction hypothesis stated that corrective feedback which arises from negotiation of meaning plays an important role in second language acquisition (SLA). Corrective feedback resulting from interaction provides learners with opportunities to focus on specific linguistic forms and thus leads to incidental implicit language learning (Long, 1996 cited in Bower \& Kawaguchi, 2011).

Teacher reaction to student errors has been examined in different ways and has taken many guises; linguists have conceptualized it as negative evidence, discourse analysts hypothesized it to be a repair strategy while psychologists examined it as negative feedback. Second language teachers clarified the term as corrective feedback, and recently 
studies conducted by Long (1990s) has provided the rational for focus-on-form in SLA. The issue of error correction under the rubric of focus-on-form has received more attention (Lyster \& Ranta, 1997).

Lyster and Ranta (1997 cited in Bower \& Kawaguchi, 2011) described corrective feedback as providing negative or positive evidence upon learners' erroneous utterances which encourages learners to repair them according to the focus of feedback with regard to accuracy or comprehensibility. Corrective feedback also provides learners with opportunities to focus on specific linguistic forms which is claimed to lead to implicit learning and increasing communicative competence. In contrast to traditional teaching method which emphasizes form of language as an end in itself, corrective feedback draws students' attention to linguistic forms in activities which focus on meaning and communication (Chu, 2011). Studies show that students who are exposed to language through form-focused activities or error correction are reported to outperform those who receive the same amount of natural classroom exposure (Lightbown \& Spada, 1990 cited in Bargiela, 2003).

Chaudron (1988) made a distinction between different functions of providing corrective feedback; it may refer to teacher behavior to make learner aware that an error has occurred. Another function of corrective feedback is to elicit revised learner response, finally, it attempts to provide learner with correct form which results in modification of the learner's interlanguage rules so that the error is not repeated.

The theoretical basis for importance of corrective feedback comes from Swain's output hypothesis. Swain $(1985,1995)$ emphasized the importance of student output in her output hypothesis as a complement to krashens' input hypothesis (Eliss, 2008). She proposed that language production helps students to move from semantic to syntactic processing since production demands grammatical knowledge, it forces students to pay attention to grammatical forms (Eliss, 2008). Swain (1985) argued that teachers are required to make students produce comprehensible and accurate language since it leads to interlanguage development. Irrespective of the strategy used by teachers, Swain (1995) argued that repair in the classroom discourse is a pedagogical tool that enhances learners' metalinguistic awareness. This is because L2 learning takes place through the exposure of learners to comprehensible input, thus learners need teachers' feedback to correct ungrammaticality (Elis, 2008). Swain (2005 cited in Abadikhah 2011) claimed that learners use their output to learn about the target language forms in a trial-and-error fashion. Corrective feedback received through interaction helps learner modify their output and this is an integral part of the second language learning process (Swain, 2005 cited in Abadikhah 2011).

Another theoretical basis for the importance of corrective feedback is related to Long's interaction hypothesis. Long (1995 cited in Bower \& Kawaguchi, 2011) asserts that corrective feedback which results from negotiation of meaning is an important aspect of language learning. Occurrence of communication breakdown in conversation demands modification from the L2 learners or their interlocutor which results in higher proficiency (Bower \& Kawaguchi, 2011). In order to be understood by the native speaker either the learner needs to modify his/her production (i.e., modified output) or the NS needs to simplify speech (i.e., modified input). Both modified input and modified output may lead to noticing of gaps in learner interlanguage (Bower \& Kawaguchi, 2011). According to de Bot (1996 cited in Lyster 2002) pushing students to retrieve target language forms is more fundamental to language development than exposing them to the forms through input, because the retrieval and production of language stimulate the development of connections in memory. Furthermore in L2 production learners perceive and identify the gaps between their interlanguage forms and the target forms (Schmidt \& Frota, 1986 cited in Panova \& Lyater, 2002).

Schmidts (1990) in his Noticing Hypothesis further claims that "noticing" of linguistic form by adult learners is important for language acquisition. His claim is based on his own experience of learning Portuguese and on his analysis of his own language development with a native speaker researcher (Schmidt \& Frota, 1986). Analysis of data showed that he could produce linguistic items which were included in input and noticed by him in the output of people around him (Eliss 2008). Schmidt (1995) therefore claims that corrective feedback plays an important role in promoting "noticing" in adult's L2 learning.

A concept related to the feedback is uptake. Slimani (1992) defined uptake as claims made by learners about what they have learned from a particular material. However Lyster and Ranta (1997) offered a different conceptualization of the uptake as follows: "student's utterance that immediately follows the teacher's feedback and that constitutes a reaction in some way to the teacher's intention to draw attention to some aspect of the student's initial utterance" (p.49). Description of uptake reveals the students' attempts to deal with the teacher's feedback, if there is no uptake, then there is topic continuation which is initiated by either the same or another student and is demonstration that the teacher's intention goes unheeded (Eliss 2008). Lyster and Ranta (1997) suggested that there are two types of student uptake: (a) uptake that results in "repair" of the error on which the feedback focused and (b) uptake that fails to correct initial utterance that still needs repair (coded as "needs-repair") (p.49). If there is no uptake, then there is topic continuation which is initiated by either the same or another student.

Sheen (2004 cited in Eliss 2008) suggested that uptake varies according to context and is likely to occur in EFL classes. Similarly Oliver (2000) found that learner uptake occurs more frequently in teacher fronted lessons than in pair work activities. He found that uptake didn't follow one-third of teacher's feedback moves. Studies of learner uptake reveals amount of student participation in the error treatment sequences and enables researchers to describe patterns of error treatment in teacher-student interaction (Panover \& Lyster 2002). 


\section{Review of Related Studies}

Suzuki (2005) studied the relationship between corrective feedback and learner uptake in adult ESL classrooms. He applied Lyster and Ranta's (1997) framework and studied patterns of corrective feedback and learner uptake in a context different from that of Lyster and Ranta's study. He analyzed data from 21 hours of interaction between three ESL teachers and thirty-one adult ESL students. Results of study revealed that frequency of types of corrective feedback given to student errors did not differ from that reported by Lyster and Ranta (1997). However the ratio of uptake following certain corrective feedback types was significantly different from Lyster and Ranta's results.

Mackey, Gass, and McDonough (2000) investigated 17 non-native speakers' interactions to find out what kinds of feedback led to increased learner perception. They found that the learners' perception of lexical, semantic, and phonological feedback was to some extent accurate; however, they did not perceive morphosyntactic feedback as applied by teacher. Regarding the relationship between the kinds of corrective feedback and learners' errors, morphosyntactic errors were addressed through recast and phonological errors were dealt with through elicitation, clarification request, repetition of the error, and metalinguistic feedback.

A major study contributing to corrective feedback and uptake in second language learning is that of Lyster and Ranta (1997) which concerns different corrective feedback types used by teachers in their interactions with students. Lyster and Ranta (1997) reported that teachers mainly provided learners with recasts, elicitation, metalinguistic feedback, clarification requests, corrective repetition, and explicit correction. This study indicated that among different kinds of corrective feedback used by the teacher, recasts were the most frequent one (55\% of whole feedback). However, it was not so effective to encourage learner uptake and repair. They stated that the ineffectiveness of recasts was due to students' assumption that there is a focus on the content by the teacher rather than the linguistic form. Lyster and Ranta (1997) reported that $18 \%$ of the feedback used was explicit correction. However, this type of feedback technique failed to lead to the learner repair. Their results indicated that the four other feedback types (elicitation, clarification requests, metalinguistic feedback and repetition) were used with lower frequency, although they were successful in elicit learner's uptake.

Roberts (1995 cited in Panover \& Lyster 2002) investigated the ability of three adult learners of Japanese to identify instances of teacher feedback in a post hoc viewing of a video recording of a 50-minute lesson in which they and other classmates had participated. The results of his study revealed that one of the learners was able to identify $46 \%$ of the feedback moves in the 50-minute segment, another identified $37 \%$, and another only $24 \%$. Recast was the predominant type of response to learner errors which comprised $60 \%$ of all feedback.

Review of existing literature related to corrective feedback reveals that the main findings of studies concerning corrective feedback and uptake are related to immersion classrooms. Further research is required to examine use of corrective feedback in different communicative EFL contexts. Thus, to bridge this gap, the present study aims to determine the patterns of teachers' corrective feedback and Learners' uptake in Iranian EFL classrooms.

\subsection{Research Questions}

1. What kinds of corrective feedback are frequently used in the classroom interactions?

2. Which of the corrective feedback lead to higher level of learner uptake?

\section{Method}

\subsection{Participants}

Data for the present study were collected from three elementary classes which consisted of 29 EFL learners. The participants were elementary EFL learners who attended English classes 4-6 terms at Dehkade Jahani Language Institute in Tabriz city. They were within 16-29 age range and were native speakers of Turkish language. The teachers were within 26-31 age range and had 3-4 years experience of teaching and hold MA degree in TOEFL.

\subsection{Data Collection}

The data for present study were collected within three weeks including eight sessions at Dehkade Jahani Language Institute in 2013. The classes chosen for this study were three elementary classes that were instructed on the basis of communicative approach. The teachers utilized meaning-focused activities and tasks, pair work, group work, role play and discussion based activities as well as Top Notch books as the main book. Story books and songs were also used as supplementary material in the classroom study. The researcher took part in each of the classes for three sessions (each session lasted 1.45 minutes) and observed the interaction between teacher and students. The teachers were informed about objectives of the study and were asked to involve students in discussions appropriate to their level and related to topics of their books.

The researcher audiotaped the sequences in teaching which involved interaction between teacher and students. The audiotaped teacher-learner interactions were then precisely transcribed and coded based on Lyster and Ranta's (1997) framework with the aim of measuring all the data according to the frequency of occurrence of each feedback and the amount of learner uptake. The transcribed data were identified within 400 minutes interaction. In order to analyze the pattern of erroneous utterances accompanied by teachers' feedback as well as students' reaction towards each feedback type, we used the framework for corrective feedback suggested by Lyster and Ranta (1997). Lyster and Ranta (1997) proposed six types of corrective feedback including explicit feedback, recast, clarification request, metalinguistic 
feedback, elicitation and repetition. It needs to be mentioned that we considered those errors which received feedback from teachers.

\subsection{Data analysis}

Analysis of the classroom interaction reveals that teacher used various corrective feedback in the course of teaching, they included explicit feedback, recast, clarification request, metalinguistic feedback, elicitation and repetition.

1. Explicit feedback: in explicit correction the teacher provides the correct form and clearly indicates that there is an error in the student's utterance (Lyster 2002).

$\mathrm{T}$ which songs are you ready to sing together?

S I don't practice this song

$\mathrm{T}$ you mean I didn't practice this song

S oh sorry! Yes I didn't practice this song.

2. Recast: recast is a reformulation of all or a part of a learner's utterance which includes non-target like forms Items are replaced by the corresponding target forms. However, the focus of the interlocutors is on meaning not language as an object Long (2007 cited in Yousefi \& Biria 2011).

a) $\mathrm{T}$ what did he become when he grew up?

$\mathrm{S}$ he be a doctor

$\mathrm{T}$ he became a doctor

$\mathrm{S}$ no reaction

b) $\mathrm{T}$ what's the whether is going to be like today?

$\mathrm{S} \quad \mathrm{I}$ think it is snow

$\mathrm{T} \quad$ I think it's going to be snowy

S silent (teacher continues discussion).

3. Clarification request: questions which makes students aware that his/her answer has been misunderstood due to an error, or that the utterance is not appropriate according to the rules of target language and a reformulation is required. Clarification requests often include phrases such as "Pardon me.", "What?", "What do you mean?" (Lyster \& Ranta 1997).

$\mathrm{T}$ what are you going to do if the whether is sunny?

$\mathrm{S}$ we put on coat

$\mathrm{T} \quad$ what?

S (silent)

$\mathrm{T} \quad$ I'm going to park, tell about your activities

$\mathrm{S} \quad$ yes, I am going to work with my friend

$\mathrm{T} \quad$ what? You are going to work with your friend?

S yes, um, (hesitation) I am playing.

4. Meta-linguistic cues: The teacher asks questions about the appropriateness of the student's utterance but she/he does not provide the target form explicitly (Lyster \& Ranta 1997).

$\mathrm{S} \quad$ why did stop running?

$\mathrm{T} \quad$ who stopped? Subject of sentence

S why did he stop running?

5. Elicitation: the teacher tries to elicit correct forms from students by asking questions. Ranta (1997 cited in Agbatogun, 2011) noted that elicitation is often used when the teacher allows the learners to complete an utterance or asks for a recast of non-target form utterance.

S Tom and his grand mother was ready.

$\mathrm{T} \quad$ Was ready? Two people

S yes, were ready.

6. Repetition: The teacher repeats the erroronus part the learner's utterance by using stress or rising intonation to focus the student's attention on the problematic part of the utterance.

$\mathrm{T} \quad$ why are you going to your grand mother's home?

$\mathrm{S} \quad$ I am going to my grand mother's home it visit?

$\mathrm{T}$ it visit (with rising intonation)

S to visit 


\section{Results}

Table 1 shows the distribution of different corrective feedback used in classroom interactions. The data contained a total of 277 teacher feedback involving 6 different feedback types. The data were identified within 400 minutes classroom interaction. It is indicated that in every 1.44 minute one corrective feedback was used by teacher. Analysis of data revealed that $39 \%$ of the corrective feedback aimed to provide students with correct form of the utterance. However $61 \%$ of correction moves aimed to provide the learner with opportunities to correct themselves. It was found that recasts categorized under input providing corrective feedback, were the most frequent corrective feedback used in classroom interaction with frequency of 108 in total of 277 moves. It contained 39\% of corrective feedback used by teachers. Output proving corrective feedback called prompts by Lyster (2002) which aimed to prompt students to self correct included various corrective feedback.17\% of the corrective feedback used by teachers was metalinguistic feedback which contained frequency of 48. Another strategy used by teachers to encourage students to self correct was elicitation feedback which was used 39 times during 400 minutes interaction; it included $14 \%$ of the total corrective feedback. Teachers also in their attempt to help output modification made use of repetition strategy with frequency of 30 and percentage rate of $11 \%$. The least frequent corrective feedback used by teachers were clarification request and explicit correction; each with frequency of 26 frequency $(10 \%)$.

The findings also showed that $40 \%$ of the corrective feedback were used to provide explicit correction of learners' utterance (explicit correction, elicitation and metalinguistic feedback) and $60 \%$ provided learners with implicit error correction (clarification request, repetition and recast).

Table 1. Frequency and percentage of corrective feedback

\begin{tabular}{lll}
\hline & Frequency & Percentage \\
\hline Explicit correction & 26 & $9.38 \%$ \\
Recast & 108 & $38.92 \%$ \\
Clarification request & 26 & $9.38 \%$ \\
Meta linguistic feedback & 48 & $17.32 \%$ \\
Elicitation & 39 & $14.07 \%$ \\
Repetition & 30 & $10.87 \%$ \\
\hline Total & 277 & $100 \%$ \\
\hline
\end{tabular}

Table 2 shows distribution of learner uptake in each of the corrective feedback. As it is demonstrated, recasts which were the most frequent corrective feedback used by teachers led to very low rate of learner uptake. Learners responded to just $27 \%$ of the feedback they received in form of recast and within this uptake rate, $18 \%$ led to repair and $9 \%$ resulted in needs repair i.e. required repair on the part of teachers. $73 \%$ of teacher recasts were not embarked on by students and resulted in topic continuation. It was also found that $91 \%$ of teachers' metalinguistic feedback which comprised $17 \%$ of total corrective feedback used in the classroom, resulted in learner uptake (repair $=70 \%$ and needs repair $=21 \%$ ). Elicitation was also a successful strategy in promoting learner uptake; $89 \%$ of teachers' attempt to elicit correct form which comprised $14 \%$ of the teachers' feedback resulted in uptake (repair $=64 \%$ and needs repair $=25 \%$ ). Other corrective feedback types including clarification request with uptake of $76 \%$ (repair $=30 \%$ and needs repair $=46 \%$ ), repetition with uptake of $66 \%$ (repair $=40 \%$ and needs repair $=26 \%$ ), and explicit correction with uptake of $53 \%$ (repair $=34 \%$ and needs repair $=19 \%$ ) were also effective in encouraging learners to attend to teacher feedback. The results further indicated that although $60 \%$ of corrective feedback was implicit and $40 \%$ of it explicit type, explicit feedback led to more learner uptake than implicit feedback. $77 \%$ of the explicit corrective feedback resulted in uptake but just $57 \%$ of implicit corrective feedback ended in learner uptake. Figure $1 \& 2$ summarizes the frequency of corrective feedback used by teachers and learner uptake.

Table 2. Frequency and percentage of learner uptake

\begin{tabular}{llll}
\hline & Repair & Needs Repair & No Uptake \\
\hline Explicit correction & 9 & 5 & 12 \\
& $34 \%$ & $19 \%$ & $47 \%$ \\
Recast & 20 & 10 & 78 \\
Clarification request & $18 \%$ & $9 \%$ & $73 \%$ \\
Meta linguistic feedback & 8 & 12 & 6 \\
& $30 \%$ & $46 \%$ & $24 \%$ \\
Elicitation & 34 & 10 & 4 \\
& $70 \%$ & $21 \%$ & $9 \%$ \\
Repetition & 25 & 10 & 4 \\
& $64 \%$ & $25 \%$ & $11 \%$ \\
& 12 & 8 & 10 \\
& $40 \%$ & $26 \%$ & $34 \%$ \\
\hline
\end{tabular}




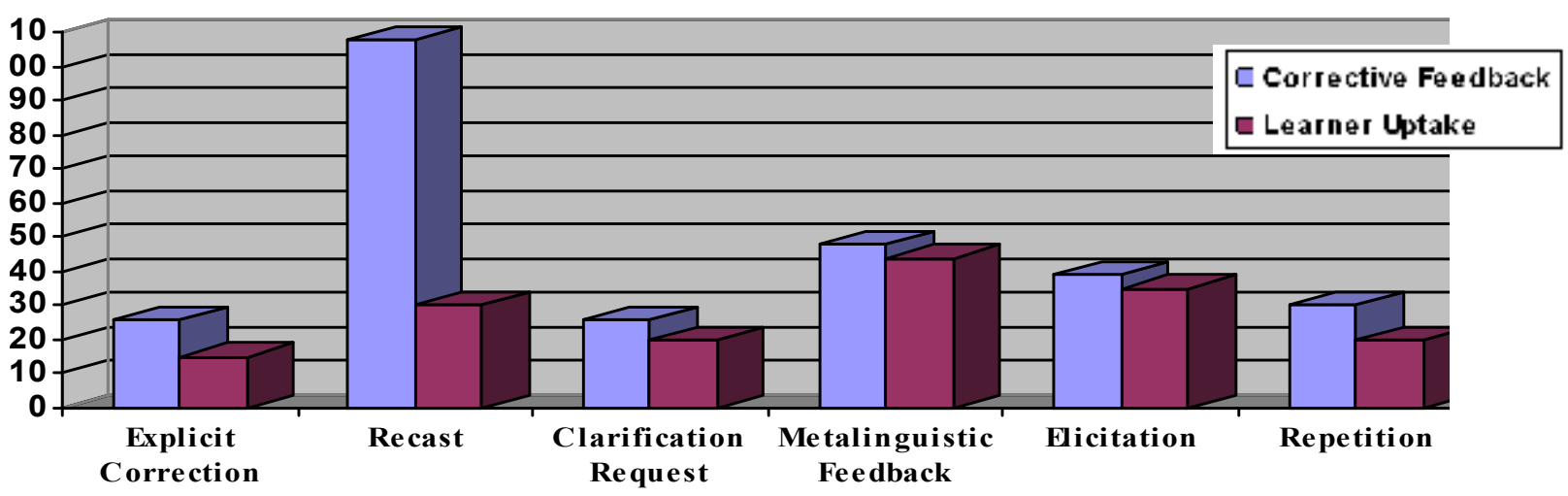

Figure 1. Frequency of different types of corrective feedback and learner uptake

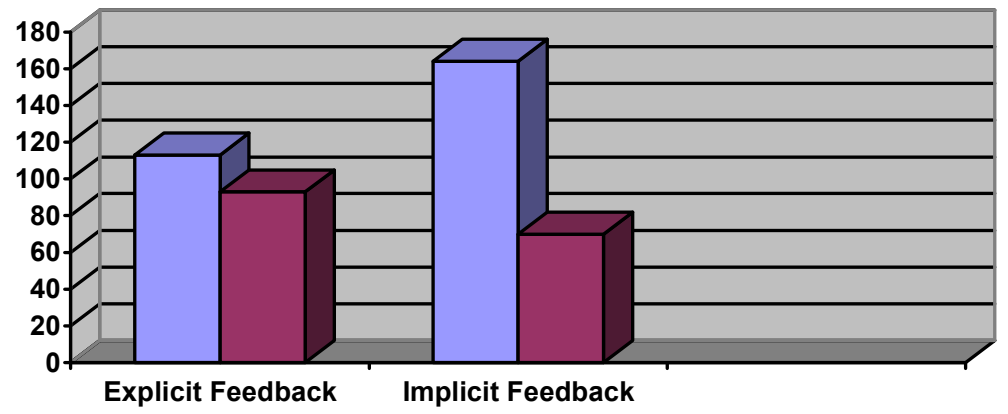

\begin{tabular}{l}
\hline Corrective Feedback \\
$\square$ Learner Uptake
\end{tabular}

Figure 2. Frequency of explicit and implicit feedback and learner uptake

\section{Discussion}

The present study aimed to investigate the kind of corrective feedback applied by teachers and learners' uptake in classroom interactions. A total of 277 teacher feedback was identified within 400 minutes interaction. It is indicated that in every 1.44 minute one corrective feedback was used by teacher. Lyster and Ranta (1997) in their study of 18.3 hours of interaction in 4 immersion classrooms at the primary level found 1372 turns with corrective feedback. So, in every 1.24 minute, one feedback was given. Lyster (1998) in his study of instruction in immersion classroom reported 921 feedback moves in 18.5 hours, a rate of one in every 1, 20 minutes. G. Samar and Shayestefar (2009) in their study of 2 EFL classrooms in Isfahan found occurrence of 169 corrective feedback turns within 240 minutes classroom interaction, that is, one feedback in every 1.54 minute. The results of the present study were to some extent similar to the findings of G. Samar and Shayestefar (2009), the reason for this would be the similarity in context since both of the studied were carried out within context of Iran which was a foreign language learning context, however; Lyster's (1998) and Lyster and Ranta's (1997) context was immersion classes.

The analysis of data also revealed that $39 \%$ of the feedback used by teachers was input providing in the form of recasts and $61 \%$ of it was output prompting corrective feedback labeled as "prompts" by Lyster (2002). The results showed that recasts in spite of high frequency of utilization by teachers did not promote student-generated repair. Only $27 \%$ of the recasts were embarked on by students, the remaining $73 \%$ went unnoticed. However, $77 \%$ of prompts led to learner uptake and only $23 \%$ of them resulted in topic continuation. It is indicated that metalinguistic feedback led to highest amount of learner uptake; $91 \%$ of this feedback was embarked on by students. Elicitation with uptake of $89 \%$, clarification request (76\%), repetition (66\%), explicit corrections $(53 \%)$ were also successful in promoting uptake. Lyster and Ranta (1997) argued that feedback types such as metalinguistic feedback, elicitation, clarification requests, and repetition of error encouraged more learner involvement in the error treatment process than do feedback types that reformulate learner errors (i.e., recasts and explicit correction). In a subsequent study, Lyster (1998) found that corrective feedback involving negotiation of form were more likely than recasts and explicit corrections to lead to repair of lexical and grammatical errors, whereas recasts were more effective in leading to repair of phonological errors.

In the same way Lyster and Ranta (1997) reported that in their study one of teachers teaching advanced class had a lower percentage of recasts; about $39 \%$ and three of the four teachers preferred to use recasts in dealing with learners' errors; $60 \%$ or more of the feedback was in the form of a recast. They concluded that the reason for this was that teachers in advanced classes make use of a greater variety of options to challenge the students. Overall, recasts were the single most frequent feedback type which comprised 55\% of corrective feedback. Lyster and Ranta (1997) expressed disapproval to recast and commented that only $31 \%$ of the recast moves led to uptake, with a fairly even distribution between repair and needs-repair. Following Lyster and Ranta (1997) and Lyster (1998), research by Panova and Lyster (2002) viewed recasts to be ambiguous to L2 learners. 
Lyster (2004 cited in Russel 2009) compared recasts to prompts for the acquisition of grammatical gender in French. He found that prompts were more effective than recasts for learners' acquisition of rule-based representations of grammatical gender. Similarly, Panova and Lyster (2002) found that students who received prompts were accurate in language production than those who received recasts. The researchers concluded that the students who received recasts did not demonstrate subsequent gains in their L2 accuracy because they had difficulty noticing their own morph syntactic errors.

Ammar and Spada (2006 cited in Ding, 2010) found that high-proficiency learners benefited equally from both prompts and recasts, whereas low-proficiency learners benefited significantly more from prompts than recasts. Considering that a second language class usually constitutes both high-proficiency learners and low-proficiency learners, it will be for the benefit of the whole class if teachers use both recasts and prompts. Recognizing the different pedagogical functions of recasts and prompts, Lyster (2002, p.251) also suggests teachers use both of them "in accordance with their students' language abilities and content knowledge ... without abandoning one at the expense of the others".

Classroom studies which compared recasts with prompts have generally reported the advantage of prompts over recasts in helping learners to achieve better learning outcomes on selected target linguistic features (Lyster, 2004; Yang \& Lyster, 2010; Ellis et al., 2006;). For example, the study of Yang and Lyster (2010), one of the few that examined the effects of recasts and prompts in a Chinese EFL setting, reported that prompts had larger effects than recasts for increasing learners' accuracy in the use of regular past tense.

A popular classification of corrective feedback is in terms of being implicit or explicit. In the case of implicit feedback, there is no overt indication that an error has been committed, whereas in explicit feedback types there is (Yang, 2008). The analysis of data in present study reveals that $41 \%$ of the corrective feedback used by teachers is explicit and $59 \%$ is implicit. Implicit corrective feedback is covertly corrective (they do not directly reveal to learner that correction of error has taken) whereas explicit feedback makes learners aware that the erroneous utterance is corrected by teacher (Ellis, 2008). Ellis (2008) views implicit/explicit distinction as reflecting a continuum rather than a dichotomy since corrective feedback is partly implicit or explicit. Researchers have argued that the implicitness/explicitness of feedback can impact learners' perception as to whether it functions as a correction, thus influencing its effectiveness. For example, the corrective intentions of recasts are reported to be easily unnoticed by learners due to their implicitness (Lyster, 1998 cited in Ding, 2011), in contrast, the corrective intention of explicit feedback types are often made more salient by overtly rejecting the erroneous utterance of learners.

Recasts are not necessarily implicit; depending on different instructional contexts and including different characteristics recasts can lie 'at various points on a continuum of linguistic implicitness-explicitness' (Ellis \& Sheen, 2006, pp. 583 cited in Ding, 2011). Lyster (2002) questioned the reliability of comparing the effects of different feedback techniques according to their implicitness/explicitness. Instead, he differentiated two categories of feedback; those that withhold correct forms and encourage learners to self-correct and the ones that provides learners with correct reformulation and therefore obviates the necessity to self-correct.

\section{Conclusion}

The present study attempted to examine application of different feedback types and learners' reaction toward each feedback in context of Iran. The results indicated that all the six feedback types suggested by Lyster and Ranta (1997) were used with different frequencies by teachers. The most frequent strategy was recast which enjoyed a lot of attention on the parts of researchers in last decade. Other feedback types were also used by teachers in their attempt to correct students' errors. It was indicated that recast was not successful in promoting student- generated repair. Only $27 \%$ of the recast led to learner uptake, the remaining amount ended in topic continuation by teacher or students. The results accentuated the effectiveness of metalinguisric feedback in enhancing learner uptake, about $91 \%$ of this strategy resulted in uptake on the part of students. Elicitation, clarification request, repetition, explicit correction also promoted learner uptake. The results of study highlighted the importance of explicit form focused instruction and metalinguistic awareness in helping students to notice the gap in their interlanguage development. Involving students in negotiation exchanges and providing negative feedback promotes output modification on the part of students. This study can be replicated to examine the effectiveness of different feedback types with students of different language proficiency level and background. Furthermore, obtaining students' attitudes toward different feedback types and examining effectiveness of them using introspected methods such as stimulated recall would produce fruitful results.

\section{Reference}

Abadikhah, Sh. \& Zarrabi, F. (2011). The effect of output tasks on the acquisition of English verbal morphemes. Theory and Practice in Language Studies, 1(11), 1549-1560.

Agbatogun, A. (2011). Promoting students' participation: communicative functions of repair in a Nigerian computer science classroom. International Journal of Business and Social Science, 2(15).

Bargiela, M. M. (2003). Teacher feedback and learners' uptake. Linguagem em (Dis)curso, Tubarão, 4(1), 81-96.

Bower, J. \& Kawaguchi, S. (2011). Negotiation of meaning and corrective feedback in Japanese English tandem. Language Learning \& Technology, 15 (1), 41-71 
Chaudron, C. (1988). Second language classrooms: Research on teaching and learning. Cambridge, UK: Cambridge University Press.

Chu, R. (2011).Effects of Teacher's Corrective Feedback on Accuracy in the Oral English of English-Majors College Students. Theory and Practice in Language Studies, 1(5), 454-459.

Doughty, C. \& J. William. (1998). Pedagogical choices in focus on form. In C. Doughty, \& J. Williams (eds.), Focus on form in classroom second language acquisition. Cambridge University Press, 197-261.

Ding, T. (2009). The comparative effectiveness of recasts and prompts in second language Classrooms. Journal of Cambridge Studies, 7(2), 83-97.

El Tatawy, M .(2002). Corrective feedback in second language acquisition, Working papers in TESOL and Applied Linguistics, 2(2), 1-19.

Ellis, R. (1993). The structural syllabus and second language acquisition. TESOL Quarterly, 27, 91-113.

Ellis, R. (2001). Some thoughts on testing grammar: An SLA perspective. In C. Elder, A. Brown, E. Grove, K. Hill, N. Iwashita, T. McNamara \& K. O"e Louglin (eds.), Experimenting in uncertainty: Essays in honor of Alan Davis. Cambridge: University Press, 251-263.

Ellis, R. (2008). The study of second language acquisition. Oxford University Press.

Ellis, R., \& Sheen, Y. (2006). Re-examining the role of recasts in L2 acquisition. Studies in Second language Acquisition, 28(4), 575-600.

Fang. X. (2010). The role of input and interaction in second language acquisition. Cross- Cultural Communication, 6,(1),11-17.

Faster, P. \& Ohta, A. (2005). Negotiation for meaning and peer assistance in second language classrooms. Applied Linguistics 26(3), 402-430.

G. Samar, R. \& Shayestefar, P. (2009). Corrective feedback in EFL classrooms: Learner negotiation strategies and uptake. Journal of English Language Teaching and Learning 52 (212), 108-134

Lightbown, P. \& N. Spada. (1990). Focus-on-form and corrective feedback in communicative language teaching: Effects on second language learning. Studies in Second Language Acquisition, 12, 529-448.

Long, M. H. (1983). Native speaker/non-native speaker conversation and the negotiation of comprehensible input. Applied Linguistics, 4, 126-141.

Long, M. H. (1996). The role of linguistic environment in second language acquisition. In W. C. Ritchie\& T. K. Bhatia (Eds.). Handbook of second language acquisition. (pp.413-463). San Diego; Academic Press.

Long, M. \& P. Robinson. (1998). Focus on form in classroom second language acquisition. In C. Doughty \& J. Williams (eds.) Focus on form: Theory, research and practice. Cambridge: Cambridge University Press, 15-41.

Lyster, R. (1998). Negotiation of form, recasts, and explicit correction in relation to error types and learner repair in immersion classrooms. Language Learning, 48, 183-218.

Lyster, R. (2002). Negotiation in immersion teacher-student interaction. International Journal of Educational Research 37, 237-253.

Lyster, R., 2004, Differential effects of prompts and recasts in form-focused instruction. Studies in Second Language Acquisition, 26(3), 399-432.

Lyster, R., and Ranta, L. (1997). Corrective feedback and learners uptake: negotiation of form in communicative classrooms. Studies in Second Language Acquisition, 19, 37 - 61.

Mackey, A., Gass, S., \& McDonough, K. (2000). How do learners perceive interactional feedback? Studies in Second Language Acquisition, 22, 471-497.

Nobuyoshi, J., \& Ellis, R. (1993). Focused communication tasks and second language. ELT Journal, 47, 203-210.

Oliver, R. (1995). Negative feedback in child NS-NNS conversation. Studies in Second Language Acquisition, 17, 459481.

Panova, I. \& Lyster, R. (2002). Patterns of corrective feedback and uptake in an adult ESL classroom. TESOL Quarterly, 36(4), $573-595$.

Rezaei, S., Mozaffari, F. \& Hatef, A. (2011). Corrective feedback in SLA: Classroom practice and future directions. International Journal of English Linguistics , 1(1), 21-29.

Russell, V. (2009). Corrective feedback, over a decade of research since Lyster and Ranta (1997): Where do we stand today? Electronic Journal of Foreign Language Teaching, 6(1), 21-31.

Safari, P. (2013). A descriptive study on corrective feedback and learners' uptake during interactions in a communicative EFL class. Theory and Practice in Language Studies, 3(7), 1165-1175

Schmidt, R. (1990). The role of consciousness in second language learning. Applied Linguistics, 11, 129-158. 
Schmidt, R. (1995). Consciousness and foreign language learning: A tutorial on the role of attention and awareness in learning. In R. Schmidt (Ed.), Attention and awareness in foreign language learning (pp. 1-63). Honolulu: University of Hawaii Press.

Schmidt, R. W., \& Frota, S. N. (1986). Developing basic conversational ability in a second language: A case study of an adult learner of Portuguese. In R. Day (Ed.), Talking to learn: Conversation in second language acquisition (pp. 237326). Rowley, MA: Newbury House.

Slimani, A.(1992). The role of topicalization in classroom language learning. System 17, 223-234.

Suzuki, M. (2005). Corrective feedback and learner uptake in adult ESL classrooms. TESOL \& Applied Linguistics. Columbia: Columbia University Press.

Swain, M. (1995). Three functions of output in second language learning. In Cook, G. (Ed.), Principle and practice in applied linguistics: Studies in Honor of H. G. Widdowson (pp. 125-144). Oxford: Oxford University Press.

Swain, M., \& Lapkin, S. (1995). Problems in output and the cognitive processes they generate: A step towards second language learning. Applied Linguistics, 16, 370-391.

White, L. (1987). Against comprehensible input: The input hypothesis and the development of second language competence. Applied Linguistics, 8, 95-110.

Yousefi, M. \& Biria (2011). Interactional feedback, task-based interaction and learner uptake. Contemporary Online Language Education Journal, 1, 1-19.

Yang, Y. and Lyster, R., 2010, Effects of form-focused practice and feedback on Chinese EFL learners' acquisition of regular and irregular past tense forms. Studies in Second Language Acquisition, 32, 235-263. 